\title{
Penerapan Model Induktif Kata Bergambar untuk Meningkatkan Keterampilan Membaca Permulaan Siswa Sekolah Dasar
}

\author{
Angelina C. O. R. Lake ${ }^{1}$, Muakibatul Hasanah ${ }^{2}$, Furaidah ${ }^{3}$ \\ ${ }^{1}$ Pendidikan Dasar-Universitas Negeri Malang \\ ${ }^{2}$ Pendidikan Bahasa Indonesia-Universitas Negeri Malang \\ ${ }^{3}$ Pendidikan Bahasa Inggris-Universitas Negeri Malang
}

\begin{tabular}{|c|c|}
\hline INFO ARTIKEL & ABSTRAK \\
\hline Riwayat Artikel: & $\begin{array}{l}\text { Abstract: This research aimed to increase the beginning reading skills of first grade } \\
\text { students of SD Inpres } 2 \text { Oepura Kupang by using inductive model of picture words. The }\end{array}$ \\
\hline Diterima: 29-07-2019 & student achievement was measured by using reading test and observation. The results \\
\hline Disetujui: $25-09-2020$ & showed that the use of the inductive model of picture words could increase the beginning \\
\hline Kata Kunci: & \\
\hline $\begin{array}{l}\text { inductive model; } \\
\text { pictorial words; } \\
\text { preparatory reading skills; } \\
\text { model induktif; } \\
\text { kata bergambar; } \\
\text { keterampilan membaca permulaan }\end{array}$ & $\begin{array}{l}\text { Abstrak: Penelitian ini bertujuan mendeskripsikan proses pembelajaran dan peningkatan } \\
\text { keterampilan membaca permulaan menggunakan model induktif kata bergambar siswa } \\
\text { kelas I SD. Penelitian ini dilaksanakan di SD Inpres Oepura } 2 \text { Kupang-NTT. Peningkatan } \\
\text { keterampilan membaca permulaan siswa melalui model induktif kata bergambar diukur } \\
\text { menggunakan tes dan lembar observasi. Hasil penelitian menunjukkan bahwa } \\
\text { penggunaan model induktif kata bergambar dapat meningkatkan keterampilan membaca } \\
\text { permulaan siswa. }\end{array}$ \\
\hline \multicolumn{2}{|l|}{ Alamat Korespondensi: } \\
\hline $\begin{array}{l}\text { Angelina C. O. R. Lake } \\
\text { Pendidikan Dasar } \\
\text { Universitas Negeri Malang } \\
\text { Jalan Semarang } 5 \text { Malang } \\
\text { E-mail: angelinalake19@gmail.com }\end{array}$ & \\
\hline
\end{tabular}

Pembelajaran membaca di sekolah dasar telah dimulai sejak awal siswa duduk di bangku kelas I. Pembelajaran membaca di sekolah dasar terbagi atas dua tahapan, yaitu membaca permulaan yang dilaksanakan di kelas I dan II, sedangkan untuk kelas III dan VI merupakan tahapan membaca lanjut. Pembelajaran membaca permulaan menekankan pada kemampuan memahami dan menyuarakan tulisan dengan intonasi yang wajar sebagai dasar bagi siswa untuk dapat membaca lanjut (Suhrianati, 2016). Pembelajaran membaca permulaan berhubungan dengan pengenalan bentuk huruf, pengenalan unsur linguistik, pengenalan hubungan ejaan dan bunyi (menyuarakan tulisan), dan melancarkan bacaan dalam taraf lambat (Tarigan, 2008). Membaca permulaan terdiri dari beberapa tahap, yaitu mengenalkan abjad pada siswa dan melatih siswa agar dapat melafalkannya dengan baik, kemudian mengeja suku kata, membaca kata, dan membaca kalimat pendek.

Pada umumnya membaca permulaan bukanlah hal yang mudah bagi siswa kelas I sekolah dasar. Dalam proses pembelajaran, acap kali guru dihadapkan dengan siswa yang mengalami kesulitan belajar membaca. Kesulitan yang dialami siswa saat membaca, yaitu kesalahan dalam mengucapkan huruf, kata, dan kalimat (Pratiwi \& Ariawan, 2017). Siswa yang tidak mampu membaca dengan baik akan mengalami kesulitan dalam mengikuti pembelajaran. Hal ini akan sangat berpengaruh pada hasil belajar siswa. Oleh karena itu, guru harus mampu menciptakan pembelajaran yang efektif sehingga siswa termotivasi untuk belajar. Guru dapat menerapkan berbagai model pembelajaran yang sesuai dengan karakteristik siswa. Berdasarkan hasil observasi dan wawancara dengan guru kelas I SD Inpres Oepura 2 Kupang, diketahui bahwa masih banyak siswa yang mengalami kesulitan dalam membaca permulaan. Hasil observasi menunjukkan bahwa dari 23 siswa kelas I, terdapat 7 siswa (30,44\%) yang dapat membaca (mengenal huruf dan membaca kata demi kata) dengan baik, sedangkan 16 siswa $(69,56 \%)$ masih mengalami kesulitan dalam membaca atau memiliki keterampilan membaca yang rendah. Kesulitan yang dialami siswa berupa ketidakmampuan dalam mengenal huruf, kesulitan membaca kata demi kata, dan kesulitan dalam menyuarakan bunyi konsonan tertentu. Selain itu, pembelajaran yang bersifat konvensional membuat siswa menjadi pasif dalam proses pembelajaran.

Berdasarkan permasalahan yang terjadi, maka perlu dilakukan perbaikan terhadap proses pembelajaran membaca permulaan di kelas I SD Inpres Oepura 2 Kupang. Oleh karena itu, dilakukan penelitian tindakan kelas dengan menerapkan model induktif kata bergambar pada proses pembelajaran dengan tujuan untuk meningkatkan keterampilan membaca permulaan siswa. Model induktif kata bergambar merupakan salah satu model yang dapat digunakan guru dalam proses pembelajaran membaca permulaan. Model induktif kata bergambar merupakan strategi berbahasa yang berorientasi pada pengajaran membaca dan 
menulis permulaan (Jiang \& Perkins, 2013). Terdapat empat tahapan dalam pembelajaran menggunakan model induktif kata bergambar, yaitu (1) pengenalan kata bergambar, (2) identifikasi kata bergambar, (3) review kata bergambar, dan (4) menyusun kata dan kalimat (Huda, 2013).

Model induktif kata bergambar memiliki kelebihan yaitu (1) gambar yang digunakan memberikan visual yang konkret, (2) siswa belajar dan berpartisipasi dengan siswa lainnya, (3) mengajarkan kata dan struktur kalimat kepada siswa berdasarkan gambar yang telah diberi nama, dan (4) membantu siswa membuat kalimat menggunakan kata-kata pada gambar dan menciptakan pemahaman tentang hubungan membaca dan menulis (Yuniyarsih, 2014). Proses pembelajaran membaca permulaan menggunakan model induktif kata bergambar diterapkan pada siswa kelas I SD Inpres Oepura 2 Kupang. Kegiatan pembelajaran membaca permulaan menggunakan model induktif kata bergambar dalam penelitian ini diadaptasi dari Bruce Joyce, Marsha Weil, dan Emily Calhoun (Joyce, dkk., 2009). Kegiatan tersebut, yaitu (1) menyajikan gambar di papan tulis, (2) mengidentifikasi gambar, (3) menggambar garis yang menghubungkan gambar dan kata, (4) membaca kata, (5) mengklasifikasi gambar, dan (6) membaca kalimat. Berdasarkan permasalahan tersebut, maka penelitian ini bertujuan (1) mendeskripsikan proses pembelajaran membaca permulaan siswa kelas I SD Inpres Oepura 2 Kupang menggunakan model induktif kata bergambar, dan (2) mendeskripsikan peningkatan keterampilan membaca permulaan siswa kelas I SD Inpres Oepura 2 Kupang menggunakan model induktif kata bergambar.

\section{METODE}

Penelitian ini termasuk jenis rancangan Penelitian Tindakan Kelas (Classroom Action Research). Model yang digunakan dalam penelitian tindakan kelas ini merupakan model yang dikembangkan Kemmis dan McTaggart (dalam Kusumah \& Dwitagama, 2012:20) dengan tiga tahapan, yaitu (1) plan, (2) act dan observe, serta (3) reflecting. Penelitian ini dilaksanakan di SD Inpres Oepura 2 Kupang-NTT pada Tahun Pelajaran 2018/2019. Subjek penelitian ini yaitu siswa kelas I dengan jumlah siswa 23 orang yang terdiri dari 12 siswa laki-laki dan 11 siswa perempuan.

Teknik pengumpulan data yang digunakan dalam penelitian ini, yaitu (1) observasi, (2) wawancara, (3) tes, dan (4) dokumen. Instrumen penelitian ini, yaitu (1) lembar panduan observasi keterlaksanaan kegiatan mengajar guru dan kegiatan belajar siswa, (2) panduan wawancara, (3) rubrik penilaian membaca permulaan, dan (4) RPP. Teknik analisis data yang digunakan dalam penelitian tindakan ini merupakan analisis data deskriptif menurut Miles dan Huberman (Sugiyono, 2016), yaitu (1) reduksi data, (2) penyajian data, dan (3) penarikan kesimpulan. Prosedur analisis data yang dilakukan dalam penelitian ini, yaitu (1) mengumpulkan dan menganalisis data aktivitas siswa dan guru serta hasil keterampilan membaca permulaan menggunakan model induktif kata bergambar, (2) menyajikan data dalam bentuk tabel agar mudah dilihat hasil perbandingan setiap siklus, (3) membuat kesimpulan untuk tindakan perbaikan selanjutnya berdasarkan hasil temuan dengan memerhatikan taraf dan kriteria keberhasilan tindakan.

\section{HASIL}

Hasil analisis data pada penelitian ini yaitu data aktivitas guru dan siswa serta keterampilan membaca permulaan siswa menggunakan model induktif kata bergambar. Aktivitas guru dalam proses pembelajaran terdiri atas tiga tahapan, yaitu tahap pendahuluan, tahap inti, dan tahap penutup. Aktivitas guru mengalami peningkatan pada setiap siklus, peningkatan tersebut dapat dilihat pada tabel 1 .

Tabel 1. Aktivitas Guru

\begin{tabular}{lccc}
\hline \multirow{2}{*}{ Tahap Pembelajaran } & \multicolumn{3}{c}{ Penilaian Aktivitas Guru } \\
\cline { 2 - 4 } & Siklus 1 (\%) & Siklus 2 (\%) & Siklus 3 (\%) \\
\hline Tahap Pendahuluan & 70,83 & 84,72 & 91,67 \\
Tahap Inti & 67,71 & 78,13 & 87,50 \\
Tahap Penutup & 66,67 & 81,25 & 91,67 \\
Rerata & 68,52 & 81,02 & 89,81 \\
\hline
\end{tabular}

Pada tabel $1 \mathrm{di}$ atas, dapat dilihat aktivitas guru pada pembelajaran membaca permulaan menggunakan model induktif kata bergambar mengalami peningkatan pada setiap siklus. Selisih peningkatan dari siklus I ke II sebesar 12,25\%, siklus II ke III sebesar 9,32\%. Hasil aktivitas siswa terdiri atas tiga aspek, yaitu antusiasme, keaktifan, dan respons. Ketiga aspek ini mengalami peningkatan pada setiap siklus, peningkatan tersebut dapat dilihat pada tabel 2. 
Tabel 2. Aktivitas Siswa

\begin{tabular}{lccc}
\hline \multirow{2}{*}{ Aspek yang Dinilai } & \multicolumn{3}{c}{ Penilaian Aktivitas Siswa } \\
\cline { 2 - 4 } & Siklus 1 (\%) & Siklus 2 (\%) & Siklus 3 (\%) \\
\hline Respons & 67,39 & 81,52 & 88,04 \\
Antusiasme & 56,88 & 73,55 & 85,87 \\
Keaktifan & 51,81 & 61,96 & 76,09 \\
Rerata & 58,70 & 72,34 & 83,33 \\
\hline
\end{tabular}

Pada tabel 1 di atas, selisih peningkatan aktivitas siswa pada setiap aspek diuraikan sebagai berikut: (1) peningkatan tertinggi pada aspek antusiasme, yaitu dari siklus I ke II sebesar 15,58\%, siklus II ke III sebesar 11,59\%; (2) aspek respons dari siklus I ke II sebesar 13,86\%, siklus II ke III sebesar 6,52\%; (3) aspek keaktifan, dari siklus I ke II sebesar 9,42\%, siklus II ke III sebesar $14,13 \%$.

Data hasil keterampilan membaca permulaan menggunakan model induktif kata bergambar diperoleh dari penilaian ketiga aspek, yaitu (1) pelafalan, (2) kelancaran, dan (3) kejelasan suara. Hasil peningkatan keterampilan membaca permulaan menggunakan model induktif kata bergambar dari siklus I-III dapat dilihat pada tabel 3.

Tabel 3. Keterampilan Membaca Permulaan

\begin{tabular}{lccc}
\hline \multirow{2}{*}{ Aspek yang Dinilai } & \multicolumn{3}{c}{ Penilaian Membaca Permulaan } \\
\cline { 2 - 4 } & Siklus 1 (\%) & Siklus 2 (\%) & Siklus 3 (\%) \\
\hline Pelafalan & 52,90 & 71,74 & 81,52 \\
Kelancaran & 48,91 & 60,51 & 76,45 \\
Kejelasan Suara & 50,72 & 53,62 & 71,38 \\
Rerata & 50,85 & 61,96 & 76,45 \\
\hline
\end{tabular}

Pada tabel 3 di atas, selisih peningkatan setiap siklus diuraikan sebagai berikut: (1) peningkatan tertinggi pada aspek kelancaran, yaitu dari siklus I ke II sebesar 11,6\%, siklus II ke III sebesar 16,03\%; (2) aspek pelafalan dari siklus I ke II sebesar $18,84 \%$, siklus II ke III sebesar 9,78\%; (3) aspek kejelasan suara dari siklus I ke II sebesar 2,9\%, dari siklus II ke siklus III sebesar $17,76 \%$

\section{PEMBAHASAN}

Pembelajaran membaca permulaan menggunakan model induktif kata bergambar di kelas I SD Inpres Oepura 2 Kupang terdiri atas enam kegiatan pembelajaran yang dilaksanakan pada setiap pertemuan dari siklus I-III. Kegiatan pembelajaran tersebut, yaitu (1) menyajikan gambar di papan tulis, (2) mengidentifikasi gambar, (3) menggambar garis yang menghubungkan gambar dan kata, (4) membaca kata, (5) mengklasifikasi gambar, dan (6) membaca kalimat. Pada setiap pertemuan dari siklus IIII guru selalu menampilkan gambar yang berbeda. Pertemuan pertama guru menyajikan tiga gambar, pertemuan kedua empat gambar, dan pertemuan ketiga lima gambar. Kegiatan pembelajaran ini sebagaimana yang dikemukakan oleh Joyce, dkk. (2009).

Kegiatan pembelajaran yang pertama yaitu menyajikan gambar di papan tulis. Pada kegiatan ini, guru meminta bantuan siswa untuk menempelkan gambar yang telah disediakan. Pada saat gambar ditempelkan siswa yang lainnya beramai-ramai menyebutkan nama gambar tersebut. Menurut Putra (2014) gambar membuat siswa lebih mudah untuk belajar karena sifatnya yang konkret.

Kegiatan kedua, mengidentifikasi gambar. Pada kegiatan ini, guru membimbing siswa untuk mengidentifikasi gambar berdasarkan apa yang mereka lihat maupun ketahui dari gambar tersebut. Secara bergiliran, guru memberikan kesempatan kepada semua siswa untuk mengidentifikasi gambar tersebut dengan tujuan agar siswa aktif dalam proses pembelajaran. Sejalan dengan pendapat Baharun (2015) bahwa siswa yang aktif merupakan kunci utama pembelajaran. Keaktifan siswa berdampak besar pada penguasaan materi maupun keterampilan yang baik.

Kegiatan ketiga, menggambar garis yang menghubungkan gambar dan kata. Pada kegiatan ini, guru meminta siswa maju ke depan kelas, menyebutkan nama gambar dan menuliskannya di papan tulis. Pada saat menulis nama gambar, siswa yang lain membantu dengan cara mengeja suku kata yang membentuk kata dari nama gambar tersebut. Setelah itu, siswa menggambar garis yang menghubungkan gambar dan kata.

Kegiatan keempat, membaca kata. Setelah memberi nama pada gambar (pada kegiatan ketiga), pada kegiatan keempat ini, guru membimbing siswa untuk mengeja suku kata, kemudian membaca kata berdasarkan gambar. Kegiatan ini dilakukan secara bergiliran hingga semua siswa mendapat kesempatan untuk membaca kata tersebut. Kegiatan ini dilakukan sebagai tahap awal belajar membaca sebagaimana yang dikemukakan oleh Nopriyanti (2012) bahwa anak mengenal bunyi huruf, suku kata, kemudian membaca kata.

Kegiatan kelima, mengklasifikasi gambar. Pada kegiatan ini, guru membimbing siswa untuk mengklasifikasi gambar berdasarkan bentuk, warna, jumlah, kegunaan, dan lain-lain. Kegiatan keenam, membaca kalimat. Pada kegiatan ini, guru menuliskan kalimat di papan tulis berdasarkan gambar-gambar yang ditampilkan. Setelah itu, guru membimbing siswa untuk 
membaca kalimat tersebut. Penilaian keterampilan membaca permulaan siswa dinilai pada kegiatan membaca kalimat. Penilaian yang dilakukan guru, yaitu (1) pelafalan, (2) kelancaran saat membaca, dan (3) kejelasan suara. Penilaian ini bertujuan untuk mengetahui keberhasilan dan peningkatan keterampilan membaca permulaan siswa dalam proses pembelajaran membaca permulaan menggunakan model induktif kata bergambar.

Penilaian yang dilakukan menjadi tolok ukur untuk memperbaiki kualitas pembelajaran selanjutnya. Sejalan dengan pendapat yang dikemukakan oleh Rusman (2014), bahwa penilaian dilakukan terhadap hasil pembelajaran untuk mengukur tingkat pencapaian kompetensi peserta didik, serta digunakan sebagai bahan penyusunan laporan kemajuan hasil belajar, dan memperbaiki proses pembelajaran. Berdasarkan hasil analisis data maka diperoleh persentase rerata aktivitas guru dan siswa, serta keterampilan membaca permulaan siswa menggunakan model induktif kata bergambar. Persentase rerata tersebut dapat dilihat pada gambar 1,2 , dan 3

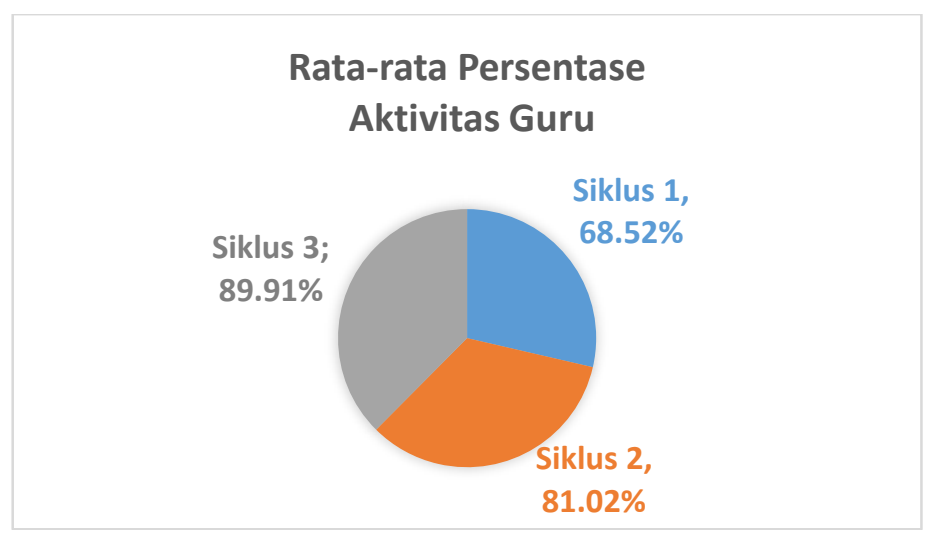

\section{Gambar 1. Grafik Peningkatan Aktivitas Guru}

Pada Gambar 1 terlihat aktivitas guru pada proses pembelajaran membaca permulaan menggunakan model induktif kata bergambar mengalami peningkatan pada setiap siklus. Rerata keberhasilan setiap siklus diuraikan sebagai berikut: (1) siklus I sebesar $68,52 \%$ berkualifikasi cukup, (2) siklus II sebesar $81,02 \%$ berkualifikasi sangat baik, dan (3) siklus III sebesar $89,81 \%$ berkualifikasi sangat baik. Aktivitas guru pada Siklus 1 belum terlaksana dengan baik, karena siswa belum terbiasa belajar membaca menggunakan model induktif kata bergambar. Pada siklus II dan III, aktivitas guru mengalami peningkatan yang baik, siswa mulai terbiasa dengan berbagai kegiatan belajar membaca menggunakan model tersebut.

Sejalan dengan hasil penelitian yang dilakukan oleh Gina, dkk. (2017), bahwa terjadi peningkatan pada pelaksanaan (aktivitas guru) saat proses pembelajaran menulis karangan narasi menggunakan model induktif kata bergambar. Persentase ratarata aktivitas siswa pada siklus I sebesar 83,33\%, siklus II (92,43\%), dan siklus III (100\%). Dari uraian di atas, diketahui bahwa penggunaan model induktif kata bergambar dapat meningkatkan aktivitas guru dalam proses pembelajaran.

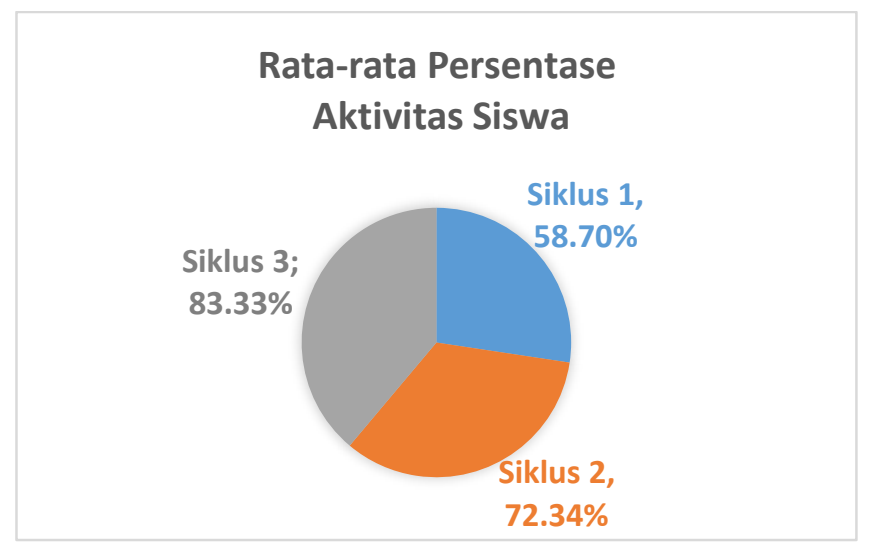

Gambar 2. Grafik Peningkatan Aktivitas Siswa

Pada gambar 2 terlihat aktivitas siswa pada proses pembelajaran membaca permulaan menggunakan model induktif kata bergambar mengalami peningkatan pada setiap siklus. Rerata keberhasilan setiap siklus diuraikan sebagai berikut: (1) siklus I sebesar 58,70\% berkualifikasi kurang, (2) siklus II sebesar 72,34\% berkualifikasi baik, dan (3) siklus III sebesar 83,33\% berkualifikasi sangat baik. 
Pada siklus I, aktivitas siswa masih sangat rendah. Hal ini disebabkan karena siswa ribut saat pembelajaran, mengganggu teman di sebelahnya, masih malu-malu dan tidak percaya diri saat melaksanakan arahan yang diberikan guru. Pada siklus II, aktivitas siswa mengalami peningkatan, namun masih ada juga siswa yang tidak tertib. Pada siklus III, aktivitas siswa mengalami peningkatan yang sangat baik, siswa mengikuti proses pembelajaran dengan baik, dapat melaksanakan arahan yang diberikan, dan tertib.

Sejalan dengan hasil penelitian yang dilakukan oleh Gina, dkk. (2017), bahwa terjadi peningkatan pada aktivitas siswa saat proses pembelajaran menulis karangan narasi menggunakan model induktif kata bergambar. Persentase rata-rata aktivitas siswa pada siklus I sebesar 72\%, siklus II (74\%), dan siklus III (100\%). Aspek yang diamati pada penelitian ini, yaitu kerja sama, mandiri, dan kreatif. Dari uraian di atas, diketahui bahwa penggunaan model induktif kata bergambar dapat meningkatkan aktivitas siswa dalam proses pembelajaran.

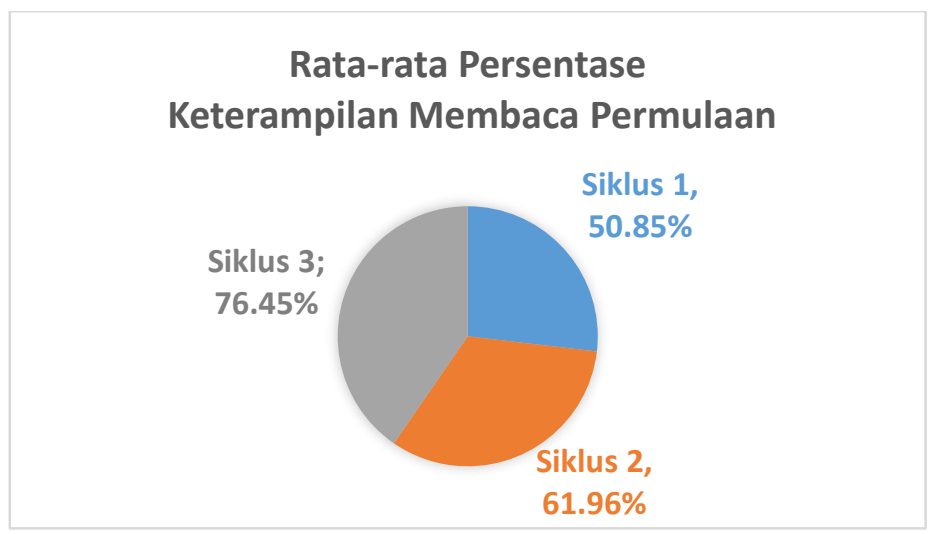

\section{Gambar 3. Grafik Peningkatan Keterampilan Membaca Permulaan}

Pada gambar 3 terlihat keterampilan membaca permulaan siswa menggunakan model induktif kata bergambar mengalami peningkatan pada setiap siklus. Rerata keberhasilan setiap siklus diuraikan sebagai berikut: (1) siklus I sebesar 50,85\% berkualifikasi kurang, (2) siklus II sebesar 61,96\% berkualifikasi cukup, dan (3) siklus III sebesar 76,45\% berkualifikasi baik.

Proses pembelajaran membaca menggunakan model induktif kata bergambar pada siklus I dan II belum terlaksana dengan baik. Siswa belum terbiasa belajar membaca dengan berbagai kegiatan yang terdapat pada model ini. Siswa juga belum lancar membaca, membutuhkan bimbingan guru agar dapat membaca kalimat hingga selesai, lafal dan volume suara yang dihasilkan saat membaca pun kurang jelas. Pada siklus III, keterampilan membaca permulaan siswa mengalami peningkatan yang baik. Siswa tidak malu-malu dan percaya diri saat membaca sehingga lafal dan volume suara yang dihasilkan lebih jelas. Selain itu, siswa pun dapat membaca kalimat hingga selesai dengan baik.

Sejalan dengan hasil penelitian yang dilakukan oleh Gina, dkk. (2017), bahwa terjadi peningkatan pada hasil belajar (menulis karangan narasi) saat proses pembelajaran menulis karangan narasi menggunakan model induktif kata bergambar. Persentase rata-rata aktivitas siswa pada siklus I (70\%), siklus II (90\%), dan siklus III (99,04\%). Dari uraian di atas, diketahui bahwa penggunaan model induktif kata bergambar dapat meningkatkan hasil belajar siswa.

\section{SIMPULAN}

Berdasarkan hasil penelitian dan pembahasan dapat disimpulkan bahwa model induktif kata bergambar telah diterapkan dengan langkah-langkah yang benar dan sesuai rancangan pembelajaran membaca permulaan yang telah disusun. Terdapat enam kegiatan pada pembelajaran membaca permulaan menggunakan model induktif kata bergambar yang dilaksanakan oleh guru dan siswa, yaitu (1) menyajikan gambar di papan tulis, (2) mengidentifikasi gambar, (3) menggambar garis yang menghubungkan gambar dan kata, (4) membaca kata, (5) mengklasifikasi gambar, dan (6) membaca kalimat.

Peningkatan aktivitas guru dan siswa serta keterampilan membaca permulaan siswa kelas I SD Inpres Oepura 2 Kupang terjadi pada setiap pertemuan dari siklus I-III. Rerata aktivitas guru dari siklus I-III, yaitu 69\%, 81\%, dan 90\%. Rerata peningkatan aktivitas siswa dari siklus I-III, yaitu (1) aspek respons (67\%, 82\%, 88\%); (2) aspek antusiasme (57\%, 74\%, 86\%); (3) aspek keaktifan $(52 \%, 62 \%, 76 \%)$. Rerata peningkatan keterampilan membaca permulaan siswa menggunakan model induktif kata bergambar dari siklus I-III, yaitu (1) aspek pelafalan (53\%, 72\%, 82\%); (2) aspek kelancaran (49\%, 61\%, 76\%); (3) aspek kejelasan suara $(51 \%, 54 \%, 71 \%)$. Dengan demikian, dapat disimpulkan bahwa penggunaan model induktif kata bergambar dapat meningkatkan keterampilan membaca permulaan siswa kelas I SD Inpres Oepura 2 Kupang.

Berdasarkan simpulan di atas, saran yang dapat disampaikan terkait dengan penelitian sebagai berikut. Pertama, guru dapat menggunakan model induktif kata bergambar sebagai salah satu model dalam pembelajaran membaca permulaan. Kedua, peneliti lainnya dapat mengembangkan penelitian sejenis yang lebih mendalam lagi dengan menambahkan aspek lainnya yang dianggap penting untuk dikaji dalam minat membaca permulaan. 


\section{DAFTAR RUJUKAN}

Akbar, A. (2017). Membudayakan Literasi dengan Program 6M di Sekolah Dasar. JPSD (Jurnal Pendidikan Sekolah Dasar), $3(1), 42-52$.

Baharun. (2015). Penerapan Pembelajaran Active Learning untuk Meningkatkan Hasil Belajar Siswa di Madrasah. Jurnal Pendidikan Pedagogik, 01(01), 34-46.

Erman. (2008). Model Belajar dan Pembelajaran Berorientasi Kompetensi Siswa. Educare (Jurnal Pendidikan dan Budaya), 5(2), $1-32$.

Gina, A. M., Iswara, P. D., \& Jayadinata, A. K. (2017). Meningkatkan Keterampilan Menulis Karangan Narasi Melalui Model PWIM (Picture Word Inductive Model) Siswa Kelas IV B SD Negeri Ketib Kecamatan Sumedang Utara Kabupaten Sumedang. Jurnal Pena Ilmiah, 2(1), 141-150.

Huda, M. (2013). Model-Model Pengajaran dan Pembelajaran: Isu-Isu Metodis dan Paradigmatis. Yogyakarta: Pustaka Pelajar.

Iswara, P. D. (2018). Pengembangan Materi Ajar dan Evaluasi pada Keterampilan Mendengarkan dan Membaca. Jurnal Mimbar Sekolah Dasar, 3(1), 89—97. 10.17509/mimbar-sd.v3i1.2359

Jiang, P., \& Perkins, K. (2013). A Conceptual Paper on the Picture Word Inductive Model Using Bruner's Constuctivist View of Learning and the Cognitive Load Theory. Interdisciplinary Journal of Teaching and Learning, 3(1), 8-17.

Joyce, B., Weil, M., \& Calhoun, E. (2009). Models of Teaching: Model-Model Pengajaran. Yogyakarta: Pustaka Pelajar.

Kusumah, W., \& Dwitagama, D. (2012). Mengenal Penelitian Tindakan Kelas. Jakarta: Indeks.

Mustikowati, D., Wijayanti, E., \& Darmanto, J. (2016). Meningkatkan Semangat Membaca dan Menulis Siswa Sekolah Dasar dengan Permainan Kata Bersambut. Briliant: Jurnal Riset dan Konseptual, 1(1), 39—42. http://dx.doi.org/10.28926/briliant.v1i1.5

Nopriyanti, L. (2012). Peningkatan Kemampuan Membaca Anak melalui Metode Fonik di Taman Kanak-Kanak Islam Adzkia Bukittinggi. Jurnal Ilmiah Pesona PAUD, 1(1), 1-10.

Patty, R. (2015). Pengembangan Model Induktif Kata Bergambar pada Pembelajaran Menulis Permulaan di Kelas II SD. Jurnal Sekolah Dasar (Kajian Teori dan Praktik Pendidikan), 24(2), 172-179.

Pratiwi, I. M., \& Ariawan, V. A. N. (2017). Analisis Kesulitan Siswa dalam Membaca Permulaan di Kelas Satu Sekolah Dasar. Jurnal Sekolah Dasar (Kajian Teori dan Praktik Pendidikan), 26(1), 69-76.

Putra, N. A. (2014). Penggunaan Media Gambar Seri untuk Meningkatkan Keterampilan Menulis Narasi pada Mata Pelajaran Bahasa Indonesia Siswa Kelas IV SDN Moahino Kabupaten Morowali. Jurnal Kreatif Online (JKO), 2(4), 230 - 242.

Rusman. (2014). Model-Model Pembelajaran (Mengembangkan Profesionalisme Guru). Jakarta: Raja Grafindo Persada.

Sugiyono. (2016). Metode Penelitian Pendidikan Kuantitatif, Kualitatif, dan R \& D. Bandung: Alfabeta.

Suhrianati. (2016). Peningkatan Aktivitas dan Kemampuan Membaca Permulaan melalui Media Pembelajaran Kartu Bergambar Siswa Kelas Satu. Jurnal Sagacious, 3(1), 37-42.

Tarigan, H. G. (2008). Membaca sebagai Suatu Keterampilan Berbahasa. Bandung: Angkasa. 